\title{
The Effects of Halal Certification and Halal Awareness on Purchase Intention of Halal Food Products in Indonesia
}

\author{
Devi Septiani ${ }^{1}$, Ahmad Ajib Ridlwan ${ }^{2 *}$ \\ ${ }^{1,2}$ Department of Islamic Economics, Faculty of Economics, Universitas Negeri Surabaya, \\ Jl. Ketintang, Surabaya 60231, Indonesia \\ e-mail: deviseptiani@mhsunesa.ac.idl',ahmadajibridlwan@unesa.ac.id*2
}

*Correspondent Author

\begin{abstract}
Halal has become part of life worldwide, and the service demand is advancing on a big scale in the industrial and economic frame. This study aims to determine the effects of halal certification and customers' halal awareness of the intention to purchase halal food products. This study belongs to the quantitative type with samples of 105 Muslim respondents. Accidental sampling is applied to sampling data. Four-point Likert scale questionnaire is utilized in data collecting which is analyzed with multiple linear regression techniques using SPSS 23 program. The results of this study indicate that halal certification variables and halal awareness both partially have positive effects on purchase intentions of halal food products. Meanwhile, the two variables simultaneously, halal certification and halal awareness, also positively influence the intention to purchase halal food products.
\end{abstract}

Keywords: halal awareness, halal certification, halal food, halal product, purchase intention

\section{Introduction}

The global Muslim population in 2017 reached 1.8 billion people, and it is expected to bloom. In the same year, the halal industry sector reached more than $\$ 2.107$ billion per year (Dinar Standard \& Thomson Reuters, 2018). As a result, revenues from the halal sector rose due to the advancing demand for halal goods. These special products are food and beverages. Halal food is profitable in countries with Muslim contributions and a Muslim majority (Ahmad et al., 2013). The growing Muslim population has increased demand for halal food products and suppliers' willingness to introduce more halal products to the market (Katuk et al., 2021; Rejeb et al., 2021).

Indonesia is the largest Muslim population country. According to BPS data, in 2010, the total Muslim population reached 207.17 million (87.18\%). Based on the Global Islamic State Report 2018/2019 on halal food and beverages consumption, Indonesia is ranked first with a total expenditure of $\$ 170$ billion (Dinar Standard \& Thomson Reuters, 2018). The food and beverages industry took a positive production growth trend in 2017 , both in the large and medium and small micro-industry, reaching $9.93 \%$ (BPS, 2018). This industry is essential to be significant market potential for the halal food and beverage industry in Indonesia.

As Allah announces, consuming halal food is one of Muslim's obligations: $O$ mankind! eat of that which is halal (lawful) [food which is good on earth], and do not follow the steps of Satan (devil) (Quran chapter 2, verse 168). Obedience and devotion have made halal a universal indicator of product quality assurance and living standards (Gillani et al., 2016). The availability of halal products is an important requirement for Muslims. Therefore, it has become necessary for the government to provide halal products, especially in countries with a majority of Muslims (Adinugraha et al., 2021; Anwar et al., 2018; Kasri et al., 2021).

The halal certification logo generally is a benchmark for Muslim and non-Muslim consumers (Billah et al., 2020; Ghadikolaei, 2016). It relates to product hygiene and safety guarantees (Awan et al., 2015). Consumers perceived halal food with confidence, believing that halal food products are healthy and clean. There is a strong belief that halal awareness among non-Muslim consumers is establishing a standard for trust, safety, quality, and hygiene (Haque et al., 2015; Nawawi et al., 2020). Non-Muslims use halal products because of their quality, also known as Halalan Thoyyiban, because there are guarantees of cleanliness, safety, and product quality throughout the entire production chain (from farm to plate) (Azam et al., 2019; Yusuf et al., 2022). Halal certifications issued by the Assessment Institute for Foods, Drugs, and Cosmetics Indonesian Ulema Council are the only official 
indicator of halal food products in Indonesia. In the last five years, the Assessment Institute for Foods, Drugs, and Cosmetics Indonesian Ulema Council has given 58,959 halal certifications from 655,725 total products in circulation (Assessment Institute for Foods Drugs and Cosmetics Indonesian Ulema Council, 2018)

In addition to halal certification, customer behavior in choosing products is also influenced by product awareness. Therefore, the required knowledge when buying and consuming halal products is crucial for Muslims. It is critical because halal-certified products are produced by Muslim producers and several non-Muslim sources (Bashir, 2019; Yunus et al., 2014). Personal intrinsic religiosity (PIR) and halal product knowledge (HPK) that enable consumers to raise awareness about the benefits of consuming halal products will increase their interest in purchasing halal products. As a result, increased efforts to improve PIR and product knowledge through religio centric-based marketing orientation, as well as increased knowledge of halal products through effective marketing communication activities, can raise consumer awareness and purchase intention for halal products (Nurhayati \& Hendar, 2020). Furthermore, cases related to food and beverages harm the company itself (Huda \& Muchlisin, 2014).

Surabaya is the most populous area in East Java. According to BPS data in 2017, the population of Surabaya is approximately 2.874 .990 people, with a Muslim population of 2.499 .116 inhabitants. Along with the increasing Muslim population and the growth of the halal market in various cities throughout Indonesia, further research is needed regarding determining factors as it has significant effects on halal product purchase intention. Therefore, based on the explanation above, the researcher took the study title, the effects of halal certification, and halal awareness on the purchase intention of halal food products.

\section{Materials and Methods}

Consumer behavior is a dynamic interaction between the influence and condition of behavior and events around the environment in which humans exchange aspects in their lives (Peter \& Olson, 2017). Customer behavior can be pictured in several stages; the stage before the purchase includes the introduction of problems, information search, alternative evaluation, the stage of purchase, and postpurchase (Kotler \& Kotler, 2012)

This study uses theory of planned behavior (TPB) from Ajzen and Fishbein as a fundamental theory to support the relationship and influence between the concept of halal and other antecedents with customers' intention to buy. According to Ajzen (Peter \& Olson, 2017), a relevant component of TPB is the attitude towards the behavior. Attitudes in this regard relate to the beliefs of collective behavior, such as the belief that the product is halal, which leads to a favorable positive attitude that ends in the intention to buy (Yoga, 2018).

\subsection{Halal Certification}

Halal certification is a security guarantee for Muslims to be able to consume halal food products according to the teachings of Muslims (Batu \& Regenstein, 2014; Nurcahyo \& Hudrasyah, 2017). Halal certification is administered in accordance with Islamic Law with the primary goal of resolving Muslim consumers' concerns about the status of a single product (Salindal, 2019). Halal approval issued by Indonesian Ulema Council after strict assessment based on sharia law is called halal certification. The process involves thorough, detailed inspection from scratch; the preparation, the ingredients, the cooking process, the serving, the kitchen, the hygiene, and the labeling, which results in halal status in the form of an Indonesian Ulema Council fatwa. Products that have passed the halal certification test by Indonesian Ulema Council are identified by the presence of the halal logo listed on the product packaging (Assessment Institute for Foods Drugs and Cosmetics Indonesian Ulema Council, 2018).

\subsection{Halal Awareness}

Awareness is the ability to feel conscious about an event and an object (Aziz \& Chok, 2013). Halal awareness is a cognizant state of a Muslim where she/he has adequate sharia knowledge of what halal is, knows the exact slaughtering process, and prioritizes halal food for consumption (Ahmad et al., 2013). The more she/he understands the halal concept, the more she/he is selective in buying and consuming any food and beverage products sold widely in society. 


\subsection{Purchase Intention}

The intention is defined as the desire to conduct behavior. Intentions are not always static but can change over time. Intentions are situations where a person is willing to engage in behavior and is considered direct behavior. The intention is a motivational factor that influences a person's behavior to do something (Zarrad \& Debabi, 2015). For example, customers' purchase intention is the desire and tendency to buy the advertised product because there is a possibility that customers will buy the product in the future (Zafar \& Rafique, 2013). The mental stage in the decision-making process in which the consumer has developed an actual willingness to act toward an object or brand is referred to as purchase intention (Garg \& Joshi, 2018; Hutter et al., 2013; Lu et al., 2014). An increase in purchase intention means an increase in the likelihood of purchase so that it can be used as an essential indicator for estimating consumer behavior (Wu, 2011).

The object of this research is Muslim customers in Surabaya. Therefore, quantitative research is chosen as the type of research. The data source used in this study is primary data obtained directly from respondents through the distribution of questionnaires containing statements relating to the research conducted.

The sampling method in this study used non-probability sampling with an accidental sampling technique, which is a sampling technique based on chance. Criteria for a sample of respondents were Muslim, Surabaya residence; proven by owning an authentic legal civilian self ID, and within 17 years old and over. Yamane formula with an error rate of 10\% (Sugiyono, 2018) is used to determine the sampling number, leading to a minimum sample size of 100 respondents. Data collection techniques in this study were conducted online and provided by the researchers in which respondents choose the available answer. Measurement data on the research questionnaire uses a Likert scale with a score range of 1-4. The research instrument test used the validity and reliability test, while the classical assumption test used the normality, multicollinearity, and heteroscedasticity tests. Hypothesis testing used a $t_{\text {test }}$ and an $\mathrm{F}_{\text {test. }}$. Multiple linear regression analysis using SPSS 23 was applied to analyze the results.

\section{Results and Discussion}

\subsection{Respondent's Answer}

The following are the results of the analysis of the respondent's answers for the halal certification variable consisting of three indicators:

Table 1. Description of Respondents' Answers to Halal

\begin{tabular}{cccc}
\hline Indicator & Mean Indicator & Category & $\begin{array}{c}\text { Interval score for the respondent's } \\
\text { answer }\end{array}$ \\
\hline 1 & 3.57 & High & High $(3.1-4)$ \\
2 & 3.49 & High & Moderat $(2.1-3)$ \\
3 & 3.53 & High & Low $(1-2)$ \\
& The Mean variable of Halal Certification & & 3.53 \\
\hline
\end{tabular}

The results can be concluded based on Table 1. The overall value of the halal certification indicator is an excellent category, with an average value of 3.53, as shown in Table 1. It shows that respondents have confidence in the Indonesian Ulema Council halal certification agency to guarantee the halal product.

There are the results of the analysis of respondent answers for the halal awareness variable consisting of four indicators, as shown in Table 2.

Table 2. Description of Respondents' Answers to Halal

\begin{tabular}{cccc}
\hline Indicator & Mean Indicator & Category & $\begin{array}{c}\text { Interval score for the respondent's } \\
\text { answer }\end{array}$ \\
\hline 1 & 3.43 & High & High $(3.1-4)$ \\
2 & 3.58 & High & Moderat $(2.1-3)$ \\
3 & 3.35 & High & Low $(1-2)$ \\
4 & 3.47 & High & 3.44 \\
\hline
\end{tabular}


Based on Table 2, it could be concluded that the overall indicator value on the halal awareness variable is in the excellent category, with an average value of 3.44. It shows that respondents have good religious awareness about halal and haram.

Table 3 shows the results of the analysis of respondent answers for the purchase intention variable consisting of four indicators.

Table 3. Description of Respondents' Answers to Purchase Intention

\begin{tabular}{cccc}
\hline Indicator & Mean Indicator & Category & $\begin{array}{c}\text { Interval score for the respondent's } \\
\text { answer }\end{array}$ \\
\hline 1 & 3.44 & High & High $(3.1-4)$ \\
2 & 3.36 & High & Moderat $(2.1-3)$ \\
3 & 3.31 & High & Low $(1-2)$ \\
4 & 3.39 & High & 3.38 \\
& Mean Variable of Purchase Intention & & \\
\hline
\end{tabular}

Based on Table 3, it can be concluded that the overall indicator value on the purchase intention variable of halal food products is in the excellent category, with an average value of 3.38. It shows that respondents who intend to buy halal food products in Surabaya tend to make purchases or consumption.

\subsection{Hypothesis Testing}

A research instrument test was previously carried out using the validity and reliability test in this study, as shown in Table $4 \& 5$. The data validity test uses a bivariate Pearson correlation. There are the results of the validity tests that have been carried out on research instruments using SPSS 23.

Table 4. Instrument Validity Test Results

\begin{tabular}{|c|c|c|c|c|c|}
\hline Variable & Questionnaire & Pearson correlation & R Table & Sig. (2-tailed) & Verification \\
\hline Halal & $\mathrm{X} 1.1$ & 0.477 & 0.3610 & 0.008 & Valid \\
\hline \multirow[t]{9}{*}{ Certification } & $\mathrm{X} 1.2$ & 0.631 & 0.3610 & 0.000 & Valid \\
\hline & $\mathrm{X} 1.3$ & 0.641 & 0.3610 & 0.000 & Valid \\
\hline & $\mathrm{X} 1.4$ & 0.724 & 0.3610 & 0.000 & Valid \\
\hline & $\mathrm{X} 1.5$ & 0.585 & 0.3610 & 0.001 & Valid \\
\hline & X1.6 & 0.570 & 0.3610 & 0.001 & Valid \\
\hline & $\mathrm{X} 1.7$ & 0.761 & 0.3610 & 0.000 & Valid \\
\hline & $\mathrm{X} 1.8$ & 0.693 & 0.3610 & 0.000 & Valid \\
\hline & X1.9 & 0.800 & 0.3610 & 0.000 & Valid \\
\hline & $\mathrm{X} 1.10$ & 0.725 & 0.3610 & 0.000 & Valid \\
\hline Halal & $\mathrm{X} 2.1$ & 0.627 & 0.3610 & 0.000 & Valid \\
\hline \multirow[t]{9}{*}{ Awareness } & $\mathrm{X} 2.2$ & 0.798 & 0.3610 & 0.000 & Valid \\
\hline & $\mathrm{X} 2.3$ & 0.671 & 0.3610 & 0.000 & Valid \\
\hline & $X 2.4$ & 0.749 & 0.3610 & 0.000 & Valid \\
\hline & $\mathrm{X} 2.5$ & 0.702 & 0.3610 & 0.000 & Valid \\
\hline & $\mathrm{X} 2.6$ & 0.658 & 0.3610 & 0.000 & Valid \\
\hline & $\mathrm{X} 2.7$ & 0.580 & 0.3610 & 0.001 & Valid \\
\hline & $\mathrm{X} 2.8$ & 0.573 & 0.3610 & 0.001 & Valid \\
\hline & X2.9 & 0.588 & 0.3610 & 0.001 & Valid \\
\hline & $\mathrm{X} 2.10$ & 0.750 & 0.3610 & 0.000 & Valid \\
\hline Purchase & Y1.1 & 0.813 & 0.3610 & 0.000 & Valid \\
\hline \multirow[t]{7}{*}{ Intention } & Y1.2 & 0.806 & 0.3610 & 0.000 & Valid \\
\hline & Y1.3 & 0.609 & 0.3610 & 0.000 & Valid \\
\hline & Y 1.4 & 0.754 & 0.3610 & 0.000 & Valid \\
\hline & Y 1.5 & 0.494 & 0.3610 & 0.006 & Valid \\
\hline & Y1.6 & 0.468 & 0.3610 & 0.009 & Valid \\
\hline & Y 1.7 & 0.818 & 0.3610 & 0.000 & Valid \\
\hline & Y1.8 & 0.822 & 0.3610 & 0.000 & Valid \\
\hline \multicolumn{6}{|c|}{ Table 5. Instrument Reliability Test Results } \\
\hline \multicolumn{2}{|c|}{ Variable } & Cronbach Alpha & Critical V & \multicolumn{2}{|c|}{ Verification } \\
\hline \multicolumn{2}{|c|}{ Halal Certification } & 0.859 & 0.06 & \multicolumn{2}{|c|}{ Reliable } \\
\hline \multicolumn{2}{|c|}{ Halal Awareness } & 0.860 & 0.06 & \multicolumn{2}{|c|}{ Reliable } \\
\hline \multicolumn{2}{|c|}{ Purchase Intention } & 0.855 & 0.06 & \multicolumn{2}{|c|}{ Reliable } \\
\hline
\end{tabular}


This study used three standard assumption tests: normality, multicollinearity, and heteroscedasticity. This study uses the Kolmogorov-Smirnov Z (1-Sample K-S) normality test. There are the results of the classic assumption test, as shown in Table 6.

Table 6. Classic Assumption Test Results

\begin{tabular}{cccc}
\hline Variable & Tolerance & VIF & Sig. \\
\hline Halal Certification $\left(\mathrm{X}_{1}\right)$ & 0.621 & 1.610 & 0.542 \\
Halal Awareness $\left(\mathrm{X}_{2}\right)$ & 0.621 & 1.610 & 0.242 \\
\hline Kolmogorov-Smirnov Z & & & 0.685 \\
Asymp. Sig. (2-tailed) & & 0.736 \\
\hline
\end{tabular}

Based on Table 6, it can be concluded that this study has a normal distribution because of the asymptotic value. Sig (2-tailed) $>0.05$. There were no symptoms of multicollinearity because the VIF value of variables $X_{1}$ and $X_{2}<10$, and the tolerance value approached number 1 . There were no symptoms of heteroscedasticity because of sig values $\mathrm{X}_{1}$ and $\mathrm{X}_{2}>0.05$.

Table 7. Test Results of Multiple Linear Regression Analysis

\begin{tabular}{lccccc}
\hline \multicolumn{1}{c}{ Variable } & $\mathrm{B}$ & Std. error & Beta & $\mathrm{t}_{\text {score }}$ & Sig \\
\hline Halal Certification $\left(\mathrm{X}_{1}\right)$ & 0.156 & 0.055 & 0.167 & 2.818 & 0.006 \\
Halal Awareness $\left(\mathrm{X}_{2}\right)$ & 0.733 & 0.056 & 0.770 & 13.020 & 0.000 \\
\hline Constanta: -1.153 & & & & & \\
Adjusted R: 20.774 & & & & \\
F Value: 179.257 & & & & \\
Significance: 0.000 & & & & \\
\hline
\end{tabular}

Based on Table 7, the multiple linear regression equation is as follows:

$$
\begin{aligned}
& Y=a+b_{1} X_{1}+b_{2} X_{2}+e \\
& Y=-1,153+0,156 X_{1}+0,733 X_{2}+e
\end{aligned}
$$

Based on Table 7, On the other hand, the halal awareness variable has a positive influence on the intention to buy halal food products in the city of Surabaya because of the value of $t_{\text {arithmetic }}$ $(2.818)>t_{\text {table }}(1.983)$ and the significance value $(0.006)<0.05$. Furthermore, the halal awareness variable has a positive influence on the intention to buy halal food products in the city of Surabaya because of the value of $t_{\text {arithmetic }}(13.020)>t_{\text {table }}(1.818)$ and the significance value $(0.000)<0.05$.

Referring to the table ANOVA, as shown in Table 7, test results obtained an $\mathrm{F}_{\text {count }}$ of 179.257. Then it can be concluded that simultaneously variables $\mathrm{X}_{1}$ and $\mathrm{X}_{2}$, affect $\mathrm{Y}$. $\mathrm{R}$ square value of 0.774 or equivalent to $77 \%$.

\section{Conclusion}

Consuming halal food is one of the Muslim obligations. The obedience and devotion have made halal a universal indicator for product quality assurance and living standards. The availability of halal products is an essential requirement for Muslims. Therefore, it has become a necessity for the government to provide halal products. Meanwhile, fostering halal awareness is important in influencing Muslim purchasing decisions to choose halal-certified products and how recognizing the characteristics of products that have been certified. The Government of Indonesia has established regulations on halal certification and has implemented it well in many products. The results of this study support the importance of halal certification and halal awareness in influencing customer purchase intention. The research results conclude that all variables affect the buying intention of Muslim customers. It means that halal certification and awareness contribute to the customers' decision to purchase halal food products in Surabaya. This research has implications for the government to build halal awareness in the industry, increase training, academic and non-academic and support regulations on halal certification, regulate the certification cost standards for SMEs, medium and large industries, and socialize the halal certification process to all sellers. The religiosity factor is a factor for future research to test its influence on the purchase intention of halal products. More samples should be collected to obtain more representative and comprehensive research results. 


\section{References}

Adinugraha, H. H., Nasution, I. F. A., Faisal, F., Daulay, M., Harahap, I., Wildan, T., Takhim, M., Riyadi, A., \& Purwanto, A. (2021). Halal tourism in Indonesia: An Indonesian council of ulama national sharia board fatwa perspective. The Journal of Asian Finance, Economics and Business, 8(3), 665-673.

Ahmad, N. A. B., Tunku Abaidah, T. N. Bin, \& Abu Yahya, M. H. Bin. (2013). A study on halal food awareness among Muslim customers in Klang valley. $4^{\text {th }}$ International Conference on Business and Economic Research (4 ${ }^{\text {th }}$ ICBER 2013) Proceeding, 1073-1087.

Anwar, M. K., Fahrullah, A., \& Ridlwan, A. A. (2018). The problems of halal certification. International Journal of Civil Engineering and Technology (IJCIET), 9(8), 1625-1632.

Assessment Institute for Foods Drugs and Cosmetics Indonesian Ulema Council. (2018). Data Sertifikasi Halal LPPOM MUI Periode 2011-2018.

Awan, H. M., Siddiquei, A. N., \& Haider, Z. (2015). Factors affecting halal purchase intention evidence from Pakistan's halal food sector. Management Research Review, 38(6), 640-660. https://doi.org/10.1108/MRR-01-2014-0022

Azam, M. S. E., Abdullah, M. A., \& Razak, D. A. (2019). Halal tourism: definition, justification, and scopes towards sustainable development. International Journal of Business, Economics and Law, 18(3), 23-31.

Aziz, Y. A., \& Chok, N. V. (2013). The role of halal awareness, halal certification, and marketing components in determining halal purchase intention among non-Muslims in Malaysia: a structural equation modeling approach. Journal of International Food and Agribusiness Marketing, 25(1), 1-23. https://doi.org/10.1080/08974438.2013.723997

Bashir, A. M. (2019). Awareness of purchasing halal food among non-Muslim consumers. Journal of Islamic Marketing, 11(6), 1295-1311. https://doi.org/10.1108/JIMA-04-2018-0077

Batu, A., \& Regenstein, J. M. (2014). Halal food certification challenges and their implications for Muslim societies worldwide. Electronic Turkish Studies, 9(11).

Billah, A., Rahman, M. A., \& Hossain, M. T. Bin. (2020). Factors influencing Muslim and nonMuslim consumers' consumption behavior: A case study on halal food. Journal of Foodservice Business Research, 23(4), 324-349. https://doi.org/10.1080/15378020.2020.1768040

BPS. (2018). Jumlah penduduk menurut wilayah dan agama yang dianut.

Dinar Standard, \& Thomson Reuters. (2018). State of the Global Islamic Economy Report 2018/19. In Dubai International Financial Centre.

Garg, P., \& Joshi, R. (2018). Purchase intention of "Halal" brands in India: the mediating effect of attitude. Journal of Islamic Marketing, 9(3), 683-694. https://doi.org/10.1108/JIMA-11-20170125

Ghadikolaei, F. S. (2016). The effect of halal signs and symptoms on consumers' purchase intention in Muslim and non-Muslim countries- a review. International Journal of Business and Management Invention, 5(7), 44-49.

Gillani, S. H. B., Ijaz, F., \& Khan, M. M. (2016). Role of Islamic financial institutions in promotion of Pakistan halal food industry. Islamic Banking and Finance Review, 3(1), 29-49.

Haque, A., Sarwar, A., Yasmin, F., Tarofder, A. K., \& Hossain, M. A. (2015). Non-Muslim consumers' perception toward purchasing halal food products in Malaysia. Journal of Islamic Marketing, 6(1), 133-147. https://doi.org/10.1108/JIMA-04-2014-0033

Huda, N., \& Muchlisin. (2014). Pengaruh label halal pada makanan fakultas agama Islam. Suhuf, 26(1), 57-66.

Hutter, K., Hautz, J., Dennhardt, S., \& Füller, J. (2013). The impact of user interactions in social media on brand awareness and purchase intention: the case of MINI on Facebook. Journal of Product \& Brand Management, 22(5/6), 342-351. https://doi.org/10.1108/JPBM-05-2013-0299

Kasri, R. A., Ahsan, A., Widiatmoko, D., \& Hati, S. R. H. (2021). Intention to consume halal pharmaceutical products: evidence from Indonesia. Journal of Islamic Marketing. https://doi.org/10.1108/JIMA-06-2021-0192

Katuk, N., Ku-Mahamud, K. R., Kayat, K., Abdul Hamid, M. N., Zakaria, N. H., \& Purbasari, A. (2021). Halal certification for tourism marketing: the attributes and attitudes of food operators in Indonesia. Journal of Islamic Marketing, 12(5), 1043-1062. https://doi.org/10.1108/JIMA03-2020-0068 
Kotler, P., \& Kotler, K. L. (2012). Manajemen pemasaran (12th ed.). Erlangga.

Lu, L.-C., Chang, W.-P., \& Chang, H.-H. (2014). Consumer attitudes toward blogger's sponsored recommendations and purchase intention: The effect of sponsorship type, product type, and brand awareness. Computers in Human Behavior, 34, 258-266. https://doi.org/10.1016/j.chb.2014.02.007

Nawawi, M. S. A. M., Abu-Hussin, M. F., Faid, M. S., Pauzi, N., Man, S., \& Mohd Sabri, N. (2020). The emergence of halal food industry in non-Muslim countries: a case study of Thailand. Journal of Islamic Marketing, 11(4), 917-931. https://doi.org/10.1108/JIMA-05-2018-0082

Nurcahyo, A., \& Hudrasyah, H. (2017). The influence of halal awareness, halal certification, and personal societal perception toward purchase intention: a study of instant noodle consumption of college student in Bandung. Journal of Business and Management, 6(1), 21-31.

Nurhayati, T., \& Hendar, H. (2020). Personal intrinsic religiosity and product knowledge on halal product purchase intention. Journal of Islamic Marketing, 11(3), 603-620. https://doi.org/10.1108/JIMA-11-2018-0220

Peter, J. P., \& Olson, J. C. (2017). Perilaku konsumen dan strategi pemasaran. Salemba Empat. Jakarta.

Rejeb, A., Rejeb, K., \& Zailani, S. (2021). Are halal food supply chains sustainable: A review and bibliometric analysis. Journal of Foodservice Business Research, 24(5), 554-595. https://doi.org/10.1080/15378020.2021.1883214

Salindal, N. A. (2019). Halal certification compliance and its effects on companies' innovative and market performance. Journal of Islamic Marketing, 10(2), 589-605. https://doi.org/10.1108/JIMA-04-2018-0080

Sugiyono. (2018). Metode penelitian kuantitatif. Alfabeta. Bandung.

Wu, K. W. (2011). Customer loyalty explained by electronic recovery service quality: implications of the customer relationship re-establishment for consumer electronics e-tailers. Contemporary Management Research, 7(1), 21-44. https://doi.org/10.7903/cmr.1101

Yoga, I. (2018). Halal Emotional Attachment on Repurrchase Intention. Journal of Economics and Business, 3(1), 95-125.

Yunus, N. S. N. M., Rashid, W. E. W., Ariffin, N. M., \& Rashid, N. M. (2014). Muslim's purchase intention towards non-Muslim's halal packaged food manufacturer. Procedia - Social and Behavioral Sciences, 130, 145-154. https://doi.org/10.1016/j.sbspro.2014.04.018

Yusuf, M., Rangkuty, D. M., Krisna, R., \& Raditio, M. E. (2022). Economic analysis of halal certification by the Halal Product Assurance Administration Agency. World Journal of Advanced Research and Reviews, 13(1), 556-564. https://doi.org/10.30574/wjarr.2022.13.1.0077

Zafar, Q., \& Rafique, M. (2013). Impact of celebrity advertisement on customers' brand perception and purchase intention. Asian Journal of Business and Management Sciences, 1(11), 53-67. https://doi.org/10.5539/ibr.v5n4p55

Zarrad, H., \& Debabi, M. (2015). Analyzing the effect of electronic word of mouth on tourists' attitude toward destination and travel intention. International Research Journal of Social Sciences, 4(4), 53-60. Retrieved from http://www.isca.in/IJSS/Archive/v4/i4/7.ISCA-IRJSS2015-019.php

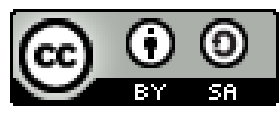

(C) 2020 by the authors. Submitted for possible open access publication under the terms and conditions of the Creative Commons Attribution (CC BY SA) license (https://creativecommons.org/licenses/by-sa/4.0/). 